\author{
Ray Riley \\ Professor, School of Environmental Design \\ and Management Portland Building \\ University of Portsmouth UK \\ Portsmouth PO1 $3 \mathrm{HE}$ \\ tel. 00442392751696 \\ ray.riley@port.ac.uk
}

\section{TYPOLOGIA I PODAŻ DZIEDZICTWA KULTUROWEGO DLA TURYSTYKI}

\section{HERITAGE TOURISM: TYPOLOGY AND SUPPLY SIDE ISSUES}

Abstract: In order to classify the means by which tourists are able to experience heritage, a five tier typology is presented: buildings, museum collections, open air museums, working museums, and the performing arts. Some supply-side issues facing heritage tourism in the UK are then discussed. These are: authenticity, education versus entertainment, re-enactment, glorious and difficult heritage, and the generation of income. It is concluded that much, if not all, heritage is presented responsibly to the tourist.

Key words: heritage tourism, heritage typology, authenticity, education v entertainment, re-enactment, glorious heritage, difficult heritage.

\section{WSTEP}

Być może określanie dziedzictwa jako czegoś, co dziedziczymy z przeszłości jest banalne, ale jednocześnie taka szeroka definicja porusza szereg kwestii, a jedną z ważniejszych jest ta, iż dziedzictwo zawiera w sobie wszystko z przeszłości. $Z$ tego stwierdzenia wyłania się pytanie: $\mathrm{z}$ czyjej przeszłości? Z pewnością muzea w XVIII i XIX w. Wielką wagę przywiązywały do zbiorów pochodzących ze starożytnych cywilizacji, kładąc nacisk na bardzo wąski wycinek dziedzictwa, tj. historię naturalną i malarstwo oraz klasyczne artefakty. Muzea były i nadal są podstawowym środkiem, poprzez który można pokazać dziedzictwo, choć dopiero stosunkowo niedawno uznano, iż naleza one do domeny turyzmu. Prawdopodobnie the Grand European Tour, w którym wzięli udział Zamożni XVIII w., a który uwzględniał nie tylko muzea i galerie sztuki, ale również architekturę

\section{INTRODUCTION}

It may be trite to define heritage as what is inherited from the past, but at the same time such a broad definition raises a host of issues, not the least of which is that logically heritage includes everything from the past. Arising out of this is the question of whose past? Certainly in $18^{\text {th }}$ and $19^{\text {th }}$ century museums great store was set upon the display of collections from ancient civilisations, just as the emphasis was upon a very narrow tranche of heritage, namely natural history and paintings, in addition to classical artefacts. Museums were, and indeed are, the primary means through which heritage may be displayed, although it was not until comparatively recently that museums have been recognised as falling within the ambit of tourism. Arguably the 
okresu klasycznego, był początkiem turystyki zorientowanej na poznanie dziedzictwa narodowego. W Wielkiej Brytanii potrzeba było nowoczesnego myślenia Księcia Alberta, małżonka Królowej Wiktorii, by zaplanować rozwój dwóch wielkich muzeów londyńskich: the Science $\mathrm{Mu}$ seum (Muzeum Nauki) (1856) oraz the Victoria and Albert Museum (1857), w dużej mierze zajmujacych się ubiorem (the Natural History Museum Muzeum Historii Naturalnej - pojawiło się później, w 1881 r.). Muzea te nie tylko powiększyły podstawę dziedzictwa, ale również stały się miejscami turystycznymi. The British Museum (Muzeum Brytyjskie) (1759) oraz the National Gallery (Galeria Narodowa) (1824) już pełnily tę funkcję. Władze lokalne miały swój wkład w proces urozmaicania poprzez otwieranie muzeów, które zajmowały się aspektami lokalnej historii, podczas gdy narodziny takich organizacji, jak the Society for the Protection of Ancient Buildings (Towarzystwo Opieki nad Zabytkowymi Budynkami) (1875) oraz the National Trust (1907), połączone z nowym prawodawstwem, takim jak Ustawa o zabytkach historycznych (the Ancient Monuments Act) z 1882 r., stwarzały warunki, by ważne budynki, jak np. średniowieczne klasztory, zamki i siedziby arystokracji, otwierały się dla turystyki.

Na początku XX w. (1920) zostało otwarte the Imperial War Museum oraz the National Maritime Museum (Narodowe Muzeum Morskie) w 1934 r., ale dopiero po II wojnie światowej rozwój turystyki zorientowanej na poznanie dziedzictwa narodowego nabrał tempa, gdy pozornie niekończący się strumień entuzjastów pragnął zachować coraz więcej obiektów dziedzictwa. $\mathrm{Z}$ drugiej strony coraz więcej osób pragnęło to dziedzictwo oglądać. Uważa się, iż $80 \%$ z 2500 muzeów i galerii sztuki w Wielkiej Brytanii zostało otwartych po 1950 r. HEwISON (1987) uważa, że ten podwójny trend wynikał $z$ utraty Imperium Brytyjskiego oraz z faktu, iż Brytyjczycy pragnęli wspominać czasy, gdy kraj był potęga - okres pewności raczej niż niepewności drugiej połowy $\mathrm{XX}$ w. Jakkolwiek ten argument ma swoją rację bytu, bardziej przekonującym wyjaśnieniem jest prosty fakt, iż Brytyjczycy posiadają silne poczucie nostalgii, co widać w niebywałym wzroście zainteresowania genealogia $w$ ostatnich trzech dekadach. Istnieje zatem motywacja, by zarówno utrzymywać obiekty dziedzictwa, jak i doświadczać ich treści. Kryją się za tym zmiany ekonomiczne i polityczne, które zredukowały tydzień pracy, pozwalając na dłuższy czas wolny, zwiększyły mo-
Grand European Tour, partaken of by the sons of the wealthy in the 18th century, which included not only museums and art galleries, but also fine architecture of the classical period, was the beginning of heritage tourism. In Britain, at least, it took the modernising influence of Queen Victoria's consort, Prince Albert, to mastermind the development of two major London museums, the Science Museum (1856) and the Victoria and Albert Museum (1857), largely concerned with dress. (The Natural History Museum came later in 1881). These museums not only broadened the heritage base, but also became places of tourism. The British Museum (1759) and the National Gallery (1824) were already fulfilling this function. Local authorities added to the process of diversification by opening museums which included aspects of local history, while the birth of organisations such as the Society for the Protection of Ancient Buildings (1875) and the National Trust (1907), together with government legislation such as the Ancient Monuments Act of 1882, encouraged the retention of, and the opening up for tourism, of important buildings such as medieval monasteries, castles, and homes of the aristocracy.

The early years of the $20^{\text {th }}$ century saw the opening of the Imperial War Museum (1920) and the National Maritime Museum in 1934, but after the Second World War the creation of heritage tourism gathered speed as a seemingly endless stream of enthusiasts sought to preserve an ever widening range of heritage objects. On the other hand demand for heritage viewing flourished. It is thought that $80 \%$ of the 2500 museums and art galleries in Britain were established since approximately 1950. HEWISON (1987) believes that this dual trend was the result of the loss of the British Empire, causing the British people to want to look back at an era when the country was a major global force, a period of certainty rather than the uncertainty of the second half of the twentieth century. While there may some substance in this argument. a more powerful explanation is simply that the British possess a strong sense of nostalgia - witness the remarkable upsurge in interest in genealogy in the last three 
bilność poprzez zastosowanie samochodów, które stały się praktycznie tańsze ze względu na innowacje technologiczne, oraz zwiększone emerytury, co pozwoliło osobom starszym cieszyć się ich czasem wolnym. Doceniając potencjalne korzyści płynące $\mathrm{z}$ turystyki zorientowanej na poznanie dziedzictwa narodowego, władze lokalne aktywnie poparły to zjawisko. Rada Miasta Portsmouth przeniosła swoje wsparcie $z$ klasycznej turystyki plażowej, należącej już do przeszłości w Wielkiej Brytanii, na turystykę zorientowaną na poznanie dziedzictwa narodowego, którego przykładem jest stocznia marynarki wojennej, historyczne rzemiosło morskie, forty, zamki i muzea militarne (RILEY 2005). W tym przypadku poglądy Hewisona maja pewne odniesienie, ale tylko na tle zmian społeczno-ekonomicznych i politycznych.

W świetle dzisiejszej złożoności turystyki zorientowanej na poznanie dziedzictwa narodowego, autor tego artykułu buduje pięciopoziomową typologię miejsc i obiektów dziedzictwa brytyjskiego, aby pojęcie to stało się jaśniejsze. Typologia ta różni się od tej zaawansowanej stworzonej przez ASHWORTA i HOWARDA (1999) tym, iż podczas gdy ich złożony siedmiokrotnie model dotyczy różnych typów dziedzictwa, zaproponowany tutaj skupia się na różnych środkach, poprzez które dziedzictwo to jest dostępne dla turysty. Cechy fizyczne, takie jak góry, jeziora, rzeki i pradawne lasy, wykluczone zostały $\mathrm{z}$ tej typologii $\mathrm{z}$ tego względu, iż $w$ większości nie są one dziełem człowieka. Uwaga skupiona jest na niektórych zagadnieniach aktywizacji w tym ważnym sektorze przemysłu turystycznego.

\section{TYPOLOGIA TURYSTYKI DZIEDZICTWA NARODOWEGO}

Przypisanie komponentów turystyki orientowanej na poznanie dziedzictwa narodowego do poszczególnych kategorii jest, mówiąc oględnie, subiektywne, w większości zależąc od punktu widzenia autora. Kategorie w sposób nieunikniony nakładają się na siebie, ale celem jest tu raczej zaproponowanie typologii miejsc, które można ulepszyć, niż postulowanie ostatecznej oceny. decades. Thus there is motivation both to set up heritage objects and to experience their contents. Behind these twin characteristics are economic and political changes which have reduced the length of the working week, enabling longer holidays, augmented mobility through the motor car, which in real terms has become cheaper as a result of technological innovation, and improved pensions, allowing the elderly to indulge their retirement. Appreciating the potential benefits to be derived from heritage tourism, local authorities have actively supported the activity. Portsmouth City Council has switched its support for bucket and spade tourism - now a thing of the past in Britain - to heritage tourism exemplified in the naval dockyard, historic naval craft, forts, castles, and military museums (RILEY 2005). In this case, Hewison's view has some relevance, but only against the back-ground of socio-economic and political change.

In the light of the present-day complexity of heritage tourism, this paper builds a five tier typology of British heritage sites and objects in an attempt to bring some clarity to the subject. The typology differs from that advanced by ASHWORTH and HOWARD (1999) in that whereas their seven-fold model is concerned with different types of heritage, that proposed here focuses on the various means through which heritage is made available to the tourist. Physical features such as mountains, lakes, rivers and ancient forests are excluded from the typology on the grounds that they are for the most part not the product of human endeavour. Attention is then directed on some of the supply-side issues raised by this important sector of the tourism industry.

\section{HERITAGE TOURISM: A TYPOLOGY}

The allocation of components of heritage tourism to particular categories is at best subjective, being largely dependent on the writer's viewpoint. There is inevitable overlap between categories, but the purpose of the exercise is to offer a typology of sites which can be improved upon rather than the postulation of definitive judgement. 


\subsection{BUDYNKI}

Wszystkie mniejsze i większe miasta posiadają klejnoty architektury historycznej, bądź to piękne domy arystokracji i patrycjuszy, bądź to zabytki, takie jak ratusze, biblioteki, muzea, galerie sztuki, katedry czy kościoły. Pod tym względem szczególnie bogate są stolice. Sektor komercyjny pozostawil po sobie wiele budynków, np. banki, hotele, teatry i stacje kolejowe, podczas gdy przemysł włókienniczy - budynki z przepięknymi fasadami. Często publikuje się trasy dla zwiedzających miasta, a w większych miastach odbywają się regularnie wycieczki prowadzone przez wykwalifikowanych przewodników. Pojawiła się turystyka miejska. Rezydencje i posiadłości arystokratów znajdujące się poza miastami są otwierane dla zwiedzających jako źródło dochodu, jednocześnie zaspokajając publiczną ciekawość stylu życia tych, co kiedyś byli prawdziwie bogaci. Stare zamki i inne budowle obronne, jak Mur Hadriana, który wyznaczał północną granicę Imperium Rzymskiego, opuszczone opactwa cystersów i mistyczne budowle, jak Stonehenge, w sposób oczywisty wzbudzają zainteresowanie turystów.

\subsection{ZBIORY MUZEALNE}

Podpunkt powyżej odnosił się do obiektów architektonicznych, ale podczas gdy niektóre muzea i galerie sztuki same w sobie posiadają wartość architektoniczna, to ich zbiory artefaktów przyciągają uwagę turystów. W miastach stołecznych znajdują się duże muzea zawierające zbiory odpowiadające zainteresowaniom ogólnym i tematycznym. The British Museum w Londynie jest typowym przykładem takiego muzeum, ze swoją kolekcją klasycznych artefaktów przyciagających thumy turystów, przynajmniej $5 \mathrm{mln}$ rocznie. Inne ważne muzea londyńskie zostały już wspomniane wcześniej. Rozwinęła się oszałamiająca wielorakość muzeów, w dużej mierze dzięki pokaźnemu rynkowi turystycznemu zapewnianemu przez wielkie miasta. Wśród przykładów z Londynu można wymienić the Museum of Garden History (Muzeum Historii Ogrodów), the Hunterian Museum, gdzie wystawione sa okazy anatomiczne, the Museum of Childhood (Muzeum Dzieciństwa), the Bank of England Museum, the Grant Museum of Zoology (Muzeum Zoologii Granta), the Chinese Art Museum (Muzeum Sztuki Chińskiej), The Museum of Freemasonry (Muzeum Wolnomularstwa), the Petrie Museum of Egyptian Archeology (Muzeum

\subsection{BUILDINGS}

All towns and cities possess historic architectural gems, whether they be fine homes of the aristocracy and well-to-do, or civic monuments such as town halls, libraries, museums, art galleries, cathedrals and churches. Capital cities are especially well endowed in this regard. The commercial sector has spawned some notable buildings such as banks, hotels, theatres and railway stations, while the textile industry in particular has generated structures with elaborate facades. It is common for town trails to be published for the benefit of tourists, and in the larger towns there are regular scheduled guided tours by accredited guides. Urban tourism has arrived. Outside the towns stately, or aristocratic, homes are open to the public as a means of generating income, at the same time satisfying the public curiosity concerning the lifestyle of the once truly rich. Ancient castles and other defensive structures such as Hadrian's Wall which marked the northern limit of Roman Britain, derelict Cistercian abbeys and mystic creations such as Stonehenge justifiably generate much tourist interest.

\subsection{MUSEUM COLLECTIONS}

Section 1. above referred to architectural structures, but while some museums and art galleries are of architectural merit, it is their collection of artefacts that sparks off tourist attention. In capital cities are to be found large museums housing collections of both general and specific interest. The British Museum in London is a fine example of the genre with its collection of classical artefacts attracting tourists in droves, 5 million a year no less. Other important London museums have already been mentioned above. Largely because of the substantial tourist market provided by capital cities, an almost bewildering range of museums has developed. Some examples from London include: the Museum of Garden History, the Hunterian Museum where are displayed preserved anatomical specimens, the Museum of Childhood, the Bank of England Museum, the Grant Museum of Zoology, the Chinese Art 
Archeologii Egipskiej Petrie) oraz Madam Tussaud's Waxworks Museum (Muzeum Figur Woskowych Madame Tussaud).

Mniejsze miasta chlubią się specjalistycznymi kolekcjami odzwierciedlającymi ich przeszłość historyczna; np. Birmingham, Manchester i Newcastle posiadaja zbiory naukowe i technologiczne. Liverpool ma muzeum morskie, wraz ze wspaniale odnowionym dokiem Alberta przez Jesse Hartleya, ukończonym w 1848 r., dwa inne muzea, księgarnię i galerię sztuki. W Chatham i Portsmouth wiele budynków wybudowanych w XVIII i XIX w. w dokach tworzy obecnie Heritage Areas (Obszary Dziedzictwa) z muzeami związanymi z działalnością morską. The Flying Boat Museum (Muzeum Latającej Łodzi) w Southampton przypomina o lotach transatlantyckich, w których lądowania odbywały się w Southampton Water. Niektóre miasta skorzystały z rządowej polityki regionalnej, wg której niektóre muzea zostały „wyjęte” spod centralnego zarządzania Londynu. The Royal Armouries Museum (Muzeum Arsenału Królewskiego) zostało przeniesione do Leeds, podczas gdy the National Railway Museum (Narodowe Muzeum Kolei) znajduje się obecnie w Yorku.

Niektóre muzea poświęcone są ważnym osobistościom związanym $\mathrm{z}$ regionem. Na przykład the Royal Naval Museum (Królewskie Muzeum Marynarki Wojennej) w Portsmouth prezentuje admirała Nelsona, podkreślając jego taktykę zastosowana przeciwko Francuzom i Hiszpanom w bitwie pod Trafalgarem w $1805 \mathrm{r}$. W niektórych przypadkach dom, w którym żył ktoś sławny, zostaje zamieniony w muzeum. Dotyczy to w szczególności osób ze świata literatury, takich jak siostry Bronte (muzeum w Howarth w Yorkshire), Jane Austen (Chawton w Hampshire) czy Charles Dickens (Portsmouth). Takie domy stanowią wielką atrakcję dla wykształconych turystów zagranicznych. W ostatnich trzech dekadach nastapił gwaltowny wzrost zainteresowania lokalną historią i taka sama uwaga została poświęcona temu zagadnieniu $\mathrm{w}$ małych muzeach. W sposób nieunikniony specyficzna natura tego trendu nie jest tak interesująca dla turystów preferujących doświadczanie dziedzictwa.

\subsection{SKANSENY}

Ogólnie rzecz ujmując, są to muzea bez ograniczeń przestrzennych typowych dla muzeów konwencjonalnych. Budowle i artefakty pozyskane gdzie indziej, mogą być rozmieszczone na dużej po-
Museum, the Museum of Freemasonry, the Petrie Museum of Egyptian Archaeology, and Mme Tussaud's Waxworks Museum.

Smaller cities have established specialist collections reflecting their historic past: Birmingham, Manchester and Newcastle, for instance, have science and technology collections. Liverpool has a maritime museum, together with an excellently refurbished Albert Dock by Jesse Hartley completed in 1848, with two museums, bookshop and an art gallery for good measure. At Chatham and Portsmouth many of the buildings in the naval dockyards constructed in the $18^{\text {th }}$ and $19^{\text {th }}$ centuries now form what are known as Heritage Areas, including museums relating to naval activities. The Flying Boat Museum at Southampton echoes the transatlantic air service which terminated at Southampton Water. Some towns have benefited from government regional policy through which some museums have been decentralised from London. The Royal Armouries Museum has been relocated to Leeds, while the National Railway Museum is now at York.

Some museums are devoted to important personalities with local associations. Hence the Royal Naval Museum at Portsmouth features Admiral Nelson, highlighting his tactics against the French and Spanish at the battle of Trafalgar in 1805. In some cases the house where the personality lived has become the museum. This applies particularly to literary figures such as the Bronte sisters at Howarth in Yorkshire, Jane Austen at Chawton in Hampshire and Charles Dickens at Portsmouth. Such houses provide a great attraction to educated foreign tourists. The last three decades have witnessed an upsurge in interest in local history, with a concomitant amount of space being allocated to the field in small museums. Inevitably, the very specific nature of this trend is of less interest to the heritage tourist.

\subsection{OPEN AIR MUSEUMS}

These are general museums lacking the space constraints of the conventional museum, allowing the structures and artefacts which have been acquired from 
wierzchni. Wśród nich znajdują się przykłady XIX-wiecznej produkcji, górnictwa, tramwajów elektrycznych, sklepów, domów mieszkalnych czy gospód (Beamish w Northumberland, Ironbridge w Shropshire lub the Black Country Museum k. Wolverhampton). Pewną odmianą tego typu muzeum jest the Weald and Download Museum w West Sussex, które posiada kolekcję XVII-XIX-wiecznych wiejskich budynków mieszkalnych i gospodarczych.

\subsection{MUZEA AKTYWNE}

Są to miejsca, w których kontynuowane są ich oryginalne funkcje, chociaż na ograniczoną skalę i nie dla zysków finansowych, a dla ,zbudowania” turysty. Takie obiekty w muzeach na otwartej przestrzeni nie są tu uwzględnione, ponieważ budynki nie znajdują się $w$ swoim oryginalnym (pierwotnym) miejscu. Modelowym przykładem jest tu fabryka włókiennicza w New Lanark w Szkocji, która jest jednocześnie obiektem na liście światowego dziedzictwa. Inne przykłady dawnych terenów przemysłowych to the Quarry Bank fabryka włókiennicza w Styal k. Manchesteru, zakład produkcji jedwabiu w Whitchurch w Hampshire, kopalnia węgla w Bleanavon oraz wiele stacji wodnych i oczyszczalni ścieków napędzanych para, np. w Kew Bridge w Londynie, Ryhope, Papplewick i Portsmouth. Wygodnie jest zawrzeć w tej kategorii zachowane linie kolei parowej, których w Wielkiej Brytanii jest ponad 50. Oryginalne są nie tylko lokomotywy, ale również wagony, towarowy tabor kolejowy, systemy sygnalizacyjne, wystrój stacji oraz mundury obsługi. Ta forma dziedzictwa jest tak popularna, iż specjalne pociągi wycieczkowe napędzane parą kursują po dzisiejszych torach ze współcześnie osiągalnymi prędkościami. W Crich w Derbyshire można podziwiać zbiór czynnych tramwajów elektrycznych.

Zachowane statki niestety nie mogą funkcjonować tak jak to było kiedyś. Przykładem tutaj jest Victory, wodowany w 1768 r., a stojący obecnie w Portsmouth, oraz Trincomalee (1817) w Hartlepool - statki marynarki wojennej. Inny statek Cutty Sark (1869) - znajdujący się w Londynie, przypomina wiek XIX, kiedy to herbata byla sprowadzana $\mathrm{z}$ Indii przez kliperów ścigających się, by dotrzeć do Londynu jako pierwsi i zapewnić sobie najwyższą cenę za ładunek. Warrior (1861), zacumowany w Portsmouth, jest pierwszym brytyjskim pancernikiem wyposażonym zarówno w ża- elsewhere to be distributed over a wide area. Featured are examples of $19^{\text {th }}$ century manufacturing, mining, electric tramways, shops, housing and the occasional pub. Examples are Beamish in Northumberland, Ironbridge in Shropshire, and the Black Country Museum near Wolverhampton. A variation is the Weald and Downland Museum in West Sussex which has a collection of $17^{\text {th }} 19^{\text {th }}$ century domestic and farm buildings.

\subsection{WORKING MUSEUMS}

These are places in which the original function is still carried out, albeit on a limited scale, and not for financial profit, for the edification of the tourist. Such structures in open air museums are not included here since the buildings are not on the original site. An outstanding example is the textile mill complex at New Lanark in Scotland, which is a world heritage site. Also exemplifying former industrial eras are the Quarry Bank textile mill at Styal, near Manchester, the silk mill at Whitchurch in Hampshire, the coal mine at Blaenavon, and numerous steampowered water and sewage pumping stations, for instance at Kew Bridge in London, Ryhope, Papplewick and at Portsmouth. In this category it is convenient to include preserved steam railway lines, of which there are more than 50 in the UK. Not only are the locomotives original, but also are the carriages, freight rolling stock, signalling systems, and station décor, in addition to staff uniforms. So popular is this form of heritage that special steam-powered excursion trains run on present-day track at present-day speeds. There is a collection of working electric trams at Crich, Derbyshire.

Perhaps not able to work as they once did are preserved vessels. Victory, launched in 1768, now at Portsmouth, and Trincomalee (1817), at Hartlepool, are naval sailing ships, while another sailing ship, Cutty Sark (1869), in London, is a relic of the days in mid-19th century when tea was brought from India by 'clippers' competing to reach London first to secure a high price for the cargo. Warrior (1861), moored at 
gle, jak i napęd parowy. Jednym z pierwszych transatlantyckich statków parowych jest Great Britain (1843) stojący w doku w Bristolu. Krazżownik z czasów drugiej wojny światowej, Belfast, zacumowany jest na Tamizie w Londynie, a łódź podwodna $\mathrm{z}$ tego samego okresu stoi w Gosport. Jest ich o wiele więcej, a wszystkie należą do głównego nurtu turystyki zorientowanej na poznanie dziedzictwa narodowego.

\subsection{PRZEDSTAWIENIA TEATRALNE}

Jeśli sprawą dyskusyjną jest to, że teatr pokazuje dziedzictwo, to jednocześnie istnieją silne argumenty przemawiające za tym, iż sztuki teatralne przekazują je w takim samym stopniu jak sztuki piękne. Zatem teatry przedstawiające prace takich dramaturgów, jak np. Szekspir, bez watpienia mieszczą się w zakresie niniejszych badań. W istocie to samo można powiedzieć o balecie lub operze, nawet jeśli to dziedzictwo ma charakter raczej międzynarodowy niż narodowy.

\section{NIEKTÓRE ASPEKTY PODAŻY}

Sklasyfikowawszy turystykę zorientowaną na poznanie dziedzictwa narodowego poprzez użycie przykładów brytyjskich, podejmijmy teraz próbę zidentyfikowania niektórych powszechnych problemów, z którymi musi się zmierzyć ten typ turystyki. Z rozmaitości działań, z których zapreZentowana powyżej typologia ilustruje zaledwie kilka, jasno wynika, że reakcje na dyskutowane problemy najprawdopodobniej też będą różnorakie. W rezultacie możemy zaledwie sformułować uogólnienia.

\subsection{AUTENTYCZNOŚĆ}

Mówiąc krótko, wystawienie na pokaz artefaktu lub budynku w jego oryginalnej postaci jest niemożliwe, ponieważ mijający czas sprawia, że Wszystkich obiektów dotyczą choćby małe zmiany. Powstaje problem, do jakiego stopnia można akceptować odchylenie od stanu oryginalnego. Powszechnie zadawane pytanie wydaje się uspraWiedliwione, zważywszy koszty, ścisłą kontrole sprawowaną przez nadzorującą organizację pod nazwą English Heritage oraz prawdopodobnie opinię publiczną. Budynki starzeją się i wymagają napraw, podobnie jak artefakty, zwłaszcza w muzeach na otwartej przestrzeni i w muzeach
Portsmouth, is Britain's first ironclad, possessing both sails and steam power. One of the first transatlantic steamships is Great Britain (1843), in dock at Bristol. A Second World War battlecruiser, Belfast, is moored on the Thames in London, and a submarine from the same era is to be found at Gosport. There are many more; all are part of mainstream heritage tourism.

\subsection{PERFORMING ARTS}

If it is argued that theatre displays heritage there is a powerful case to suggest that plays convey heritage as much as fine art - then theatres offering the works of playwrights such as Shakespeare fall squarely within the ambit of this research. Indeed, the same may be said of ballet and opera, even if in these cases the heritage is more international than national.

\section{SOME SUPPLY-SIDE ISSUES}

Having classified heritage tourism through the use of British examples, an attempt is now made to identify some common supply-side issues faced by heritage tourism. With such a plethora of heritage activities, of which the above typology illustrates but a few, it is clear that the supply-side responses to the problems discussed are likely to exhibit great variation; what follows can therefore constitute only generalisations.

\subsection{AUTHENTICITY}

Strictly, the task of exhibiting an artefact or building in its original form is an impossibility, since time ensures that changes, maybe sometimes small, are effected to all objects. The extent to which variation from the original condition is acceptable becomes the question. Each provider reaches a conclusion that seems justifiable, bearing in mind costs, the tight control exercised by the watchdog English Heritage, and the likely opinion of the public. Buildings age and need repairs, as do artefacts, especially when in open air museums and in working 
aktywnych (pracujących), nie powinniśmy więc spodziewać się absolutnej autentyczności. Ponadto rządowe przepisy dotyczące zdrowia i bezpieczeństwa oraz umożliwiania dostępu do różnych miejsc inwalidom, wymagają wprowadzania zmian, takich jak wyjścia ewakuacyjne, barierki odgradzające ruchome wyposażenie czy rampy i windy dla osób na wózkach inwalidzkich. Oświetlenie elektryczne uważa się dziś za rzecz oczywista, ale do wczesnych lat XX w. normą były lampy gazowe i parafinowe; zwiedzający muszą pohamować swoje niedowierzanie, nawet jeśli są na tyle spostrzegawczy, by zauważyć brak autentyczności.

Pomijając fakt, iż artefakty wystawione w muzeach ogólnotematycznych są zazwyczaj prezentowane bez kontekstu, trzeba powiedzieć, że przeważnie są one autentyczne. Jednakże twórcy muzeów na otwartej przestrzeni muszą liczyć się $\mathrm{z}$ faktem, iż wykreowali całkowicie sztuczne środowisko. Budowle są przebudowywane, tworząc układy przestrzenne, które nigdy nie występowały w rzeczywistości. Nacisk jest raczej kładziony na zestawienie ze sobą grupy artefaktów, które zainteresują zwiedzającego, niż na próby odtworzenia autentycznego środowiska, nawet jeśli np. sklep mięsny, apteka i tramwaje elektryczne są same w sobie bliskie autentycznym.

Krytyka może być słusznie kierowana pod adresem muzeów, których zawartość jest po prostu nieautentyczna, czego przykładem może być Charles Dickens Birthplace oraz Museum w Portsmouth. Słynny pisarz mógł rzeczywiście urodzić się w tym miejscu, ale przeprowadził się do Chatham $\mathrm{z}$ całą rodzina, gdy miał zaledwie kilka miesięcy. Z wyjątkiem szezlongu, na którym zmarł, oraz kilku stron papieru, wszystko, co jest wystawione nie należało do Dickensa; muzeum jest, wg opinii kuratora, domem urządzonym zgodnie $z$ panującą na początku XIX w. moda. Uważa się zatem, że niedoskonałości ekspozycji mogą być zaakceptowane. Dylemat dotyczy wielu muzeów poświęconych życiu osobowości historycznej. Jeśli ta osoba jest odpowiedzialna za wytworzenie artefaktów zgromadzonych razem jako kolekcja, trudno wówczas stawiać zarzut nieautentyczności. Przykładem są tu bardzo szczególne meble w stylu art nouveau zaprojektowane przez Charlesa Rennie Mackintosha, znajdujące się w Glasgow. Podobne są galerie sztuki, których zawartość jest całkowicie autentyczna.

Ponieważ muzea aktywne posiadają eksponaty, które nadal są w użytku, muszą one w sposób natu- museums, making it unreasonable to expect absolute authenticity. Furthermore, government health and safety regulations, and rules regarding access for the handicapped, require changes such as fire escapes, barriers fencing off moving equipment, and ramps and lifts for wheelchairs. Electric lighting is now taken for granted, but until the early years of the twentieth century gas lighting and paraffin lamps were the norm; visitors have to suspend their disbelief, should they be sharp enough to appreciate the lack of authenticity.

Setting aside the fact that the artefacts displayed in general museums are usually displayed out of context, it should be said that the artefacts themselves are normally authentic. However, open air museums must face the fact that they have created an entirely artificial environment. Structures are rebuilt on site creating the kind of juxtaposition that never occurred in reality. The emphasis is upon putting together a range of artefacts that will entertain the visitor, rather than endeavouring to establish an authentic environment, even if the butcher's shop, pharmacy and electric trams, for instance, are in themselves close to authentic.

Criticism may fairly be levelled at museums whose contents are simply inauthentic. A case in point is the Charles Dickens Birthplace and Museum at Portsmouth. The famous $19^{\text {th }}$ century author may have been born on the premises, but he moved to Chatham with his family when he was only a few months' old. With exception of the chaise longue on which he died and some papers, nothing belonging to Dickens is displayed; the museum is in effect a house decorated in a manner that the curator believes was fashionable in the early $19^{\text {th }}$ century. The shortcomings of the display are thus thought to be acceptable. The dilemma is one applicable to many museums dedicated to the life of an historic personality. Should the personality have been responsible for the production of artefacts which are brought together as a collection, then the claim of inauthenticity can hardly be made. Such an instance is the highly distinctive art nouveau furniture designs of Charles Rennie Mackintosh, held 
ralny nosić znamiona zużycia, a więc być reperowane lub wymieniane, niekoniecznie przy użyciu tych samych materiałów. Przepisy zdrowotne i bezpieczeństwa moga wymagać modyfikacji: np. wyściólka azbestowa używana w celu zatrzymywania ciepla w boilerach i cylindrach parowych może nie być już stosowana, ponieważ wiadomo, iż wywoluje raka płuc. W niektórych zachowanych przepompowniach wody mogą być używane silniki elektryczne lub sprężone powietrze do uruchomienia maszynerii, ale sama maszyneria jest oryginalna. Wiele zachowanych linii kolejowych używa parowozów i taboru kolejowego, które nigdy by się nie pojawiły w celach komercyjnych; polityka ta polega na tym, by zbierać wszystko, co można zaoferować i na co można sobie pozwolić, prezentując $w$ ten sposób różnorodność sprzętu. W przypadku niektórych zachowanych statków, które są oczywiście ważnymi atrakcjami dziedzictwa, problem autentyczności staje się bardzo palący. Victory i Trincomalee były statkami szkoleniowymi pod koniec swojej kariery w marynarce i zostały ponownie wyposażone $w$ artefakty i nowoczesne repliki pochodzące głównie z początków XIX w. $\mathrm{Na}$ przykład muszkiety na Victory zostały wyprodukowane w Pakistanie w latach 80. XX w. Great Britain był kolosem porzuconym na Falklandach zanim sprowadzono go $\mathrm{z}$ powrotem do Bristolu, podczas gdy Warrior był wykorzystywany jako ponton w Pembroke Dock zanim został ocalony. Wynika z tego, że właściwie wszystko na tych statkach, wyjąwszy ich kadłuby, jest nieautentyczne. Dla porównania, z kadłuba Mary Rose, wodowanego w 1500 r. i zatopionego w roku 1545, zostało tak niewiele, iż kuratorzy nawet nie podjęli próby odbudowania drewnianej konstrukcji wystawionej w Portsmouth. Pomimo to, miejsce to jest odwiedzane przez 300000 osób każdego roku.

Kierownictwo miejsc dziedzictwa dużo uwagi poświęca zasadzie autentyczności i oczywiste jest, że do jej osiagnięcia opracowano różne rozwiązania. Gdyby autentyczność była czynnikiem nadrzędnym, ani jeden ze wspomnianych statków dziś by nie istnial. Dziedzictwo brytyjskie byłoby uboższe, a turysta nim zainteresowany dużo by stracil.

To samo dotyczy muzeów na otwartej przestrzeni i innych, którym brakuje autentyczności. Pojęcie to trzeba więc przeciwstawić innym względom. in Glasgow. Similar are art galleries, whose contents are entirely authentic.

Since working museums contain art.efacts that are used, they must consequently suffer from wear and tear and be repaired or replaced, not necessarily with the same material. Health and safety regulations may require modifications: for instance, the asbestos cladding used to help retain heat in boilers and steam cylinders may no longer be employed since it is known to cause lung cancer. In some preserved water pumping stations electric motors or compressed air may be used to drive machinery, but the machinery itself is original. Many preserved railway lines use locomotives and rolling stock that would never have appeared during commercial operations; it is policy to collect whatever is on offer and can be afforded, thus creating a hotchpotch of equipment. In the case of some preserved ships, which are of course major heritage attractions, the issue of authenticity becomes very real. Victory and Trincomalee were training ships at the end of their naval careers, and have been reequipped with artefacts and modern replicas mostly dating from the early $19^{\text {th }}$ century. The muskets on Victory, for instance, were manufactured in Pakistan in the 1980s. Great Britain was a derelict hulk in the Falkland Islands prior to being brought back to Bristol, while Warrior was used as a pontoon in Pembroke Dock before its salvage. Thus virtually everything save the hull in the two latter ships is inauthentic. By contrast, there is so little left of the hull of Mary Rose, launched in 1509 and sunk in 1545, that the curators have made no attempt to add to the wooden frame on display at Portsmouth. Nonetheless, 300,000 people visit the site every year.

The principle of authenticity is given due consideration by the management of heritage sites, and it is clear that different solutions have been arrived at. Had authenticity been the controlling factor, not one of the refurbished vessels mentioned would exist. British heritage would be the poorer and so would the heritage tourist.

The same holds for the open air and other museums which lack a degree of authenticity. The notion thus has to be set against other considerations. 


\subsection{EDUKACJA A ROZRYWKA}

Od lat 70. dwa czynniki decydują o włączeniu idei rozrywki do turystyki zorientowanej na poznanie dziedzictwa narodowego. Po pierwsze konkurencja pomiędzy miejscami dziedzictwa wzrastała w miarę jak rosła ich liczba, a po drugie muzea publiczne zaczęły odczuwać skutki redukcji funduszy i zostały zmuszone do znalezienia sposobu, by zwiększyć liczbę odwiedzających. Muzea prywatne, silnie zależne od liczby gości, musiały zrobić to samo. Przyjęta strategia zakładała, by miejsca dziedzictwa uczynić bardziej interesującymi dla szerszego spektrum społecznego, zwłaszcza dla dzieci. Proces ten nosi nazwę dumbing down - upraszczanie; jest to zwrot ukuty przez amerykański przemysł filmowy w latach 30. Celem wizyty w miejscu dziedzictwa jest nauczenie się czegoś, więc próby uczynienia takich miejsc ciekawszymi były uważane przez niektórych za ruch wsteczny. W rzeczy samej, użycie nieodpowiedniej muzyki granej na żywo, organizacja pokazów ogni sztucznych i rozrywki dla dzieci, jak zjeżdżalnie i batuty, podczas dni otwartych w Portsmouth ma więcej wspólnego $\mathrm{z}$ rozrywką niż z edukacją.

$\mathrm{Z}$ drugiej strony, patrząc na tę sytuację bez emocji, rozrywka może wspomagać edukację. Wprowadzenie wystaw telewizyjnych aktywowanych przez zwiedzających, mówiących głów naturalnie wyglądających sztucznych postaci, których twarze poruszają się podczas mowy, elektronicznie kontrolowanych paneli informacyjnych, filmów wprowadzających wyświetlanych w maleńkich salach projekcyjnych, tablic z pytaniami zmuszającymi zwiedzających do myślenia oraz obsługi w odpowiednio dobranych strojach, zamiast mundurków w stylu wojskowym - wszystko to wytwarza przyjazną interaktywną atmosferę, sprzyjającą uczeniu się. Dumbing down sugeruje poziom uproszczenia, które stoi w opozycji do edukacji, jednakże doświadczenie $\mathrm{z}$ brytyjskich miejsc dziedzictwa pokazuje, iż tego typu wysiłki, by poszerzyć zainteresowania gości, raczej wspomagały niż utrudniały proces edukacyjny.

\subsection{INSCENIZACJE}

Wobec starań, by miejscom dziedzictwa dodać realizmu, powszechna stała się praktyka włączania ludzi w odtwarzanie scen historycznych poprzez zastosowanie odpowiedniego stroju. Strategia ta ma swoje zalety, ponieważ z pewnościa

\subsection{EDUCATION VERSUS ENTERTAINMENT}

From the 1970s two factors combined to introduce the idea of entertainment into heritage tourism. Firstly, there was increasing competition between heritage sites as their number increased, and secondly public museums began to suffer from a reduction in funding, forcing them to look at ways of improving their visitor numbers. Private museums, heavily dependent on visitor numbers, were obliged to do the same. The strategy was to make heritage sites more interesting and more appealing to a wider spectrum of society, especially children, a process known as dumbing down, a phrase coined by the American film industry in the 1930s. Arguably the object of a visit to a heritage site is to learn something, that is, to educate, so attempts to make such sites more entertaining were regarded by some as retrograde. Indeed, the use of inappropriate live music, firework displays and children's amusements such as slides and trampolining at open days at Portsmouth Dockyard is much more entertainment than education.

On the other hand, looking at the situation dispassionately, entertainment can in fact assist education. The introduction of television displays activated by visitors, of talking heads comprising realistic dummies whose faces move as they speak, of electronically controlled information panels, of introductory films in small cinemas, of question boards making people think, and of attendants in appropriate clothing rather than in military style uniforms, all make for a friendly and interactive environment, conducive to learning. Dumbing down suggests a level of simplification such as to be contrary to education. However, the evidence from British heritage sites suggests that on balance the efforts to widen visitors' interest have assisted rather than impeded the education process.

\subsection{RE-ENACTMENT}

In an attempt to add an element of realism to heritage sites, it has become common to incorporate people in appropriate dress reenacting historic scenes. The strategy has advantages for it certainly catches tourists' 
przyciaga uwagę turystów i w wielu przypadkach pozwala im zadawać aktorom pytania. W Quarry Bank i NewnLanark osoby obsługujące stare maszyny przędne i tkackie z przyjemnością rozmawiają ze zwiedzającymi. Niektóre muzea idą w kierunku teatru, zazwyczaj z myślą o dzieciach, inscenizując sceny $\mathrm{z}$ życia, np. służby $w$ domach arystokracji w wieku XIX. Pracownicy muzeum ubrani są w kostiumy $\mathrm{z}$ epoki, co $\mathrm{z}$ pewnością dodaje realizmu. Tylko ekspert mógłby stwierdzić, czy noszone przez nich ubranie jest autentyczne czy nie, nawet jeśli nowoczesne okulary, zegarki i buty swoim anachronizmem nieco psują ogólny efekt.

The Royal Armouries Museum potraktowało rekonstrukcję poważnie, zatrudniając zawodowych aktorów, by odgrywali sceny wojenne. Aktor gra rolę żołnierza w bitwie pod Rorke's Drift z Zulusami w 1879 r. i opowiada o swoich myślach podczas dramatycznej walki, kiedy to strzela do wroga i kiedy giną jego towarzysze broni. Zrozumiałe jest, że dzieci są nieco przytłoczone przedstawieniem, ale na pewno go dhugo nie zapomną. $\mathrm{Na}$ koniec aktor prosi o pytania. To najczęściej zadawane dotyczy autentyczności: skąd aktor wie co się stało? Skąd może wiedzieć, o czym myślał ktoś, kto żył ponad wiek wcześniej, kiedy były zupelnie inne wartości? Czy strzelba i mundur naprawdę tak wyglądały? Jednak wszystko, co aktor może powiedzieć to to, iż wg badań wszystko jest autentyczne. Te same kwestie ogólne pojawiają się przy odtworzeniu postaci oficera z okresu II wojny światowej, który gloryfikuje bitwę, oraz innego, który jest przybity głupotą wojny. Taka rekonstrukcja bez wątpienia pozostawia trwałe wrażenie na turyście. I choć trochę rozczarowuje, że ślepe pociski w działach z czasów II wojny światowej wystrzeliwane są przez mężczyzn ubranych w jeansy, to jednak towarzyszący wystrzałom huk, dym i błysk całkowicie pochłaniają uwagę publiczności.

Podobnie zajmujące mogą być inscenizowane bitwy, ale ich autentyczność jest wątpliwa, nawet gdy odbywają się dokładnie w tym samym miejscu co wydarzenie historyczne. Przykładem może być bitwa pod Culloden w Szkocji, ostatnia bitwa stoczona w Wielkiej Brytanii w 1746 r., kiedy to szkoccy górale zostali rozgromieni przez armię brytyjska. Miejscem bitwy jest po prostu pole, gdzie wydarzenie jest odgrywane. Zwiedzający mają do dyspozycji punkt, w którym mogą znaleźć informację wizualną. Trudno jednak attention, and in many cases allows questions to be put to the actors. At Quarry Bank mill and at New Lanark operatives working old spinning and weaving machinery are pleased to converse with the public. Some museums move towards theatre, having special performances, usually aimed at children, taking up particular themes, for instance, servants' life in $19^{\text {th }}$ century homes of the aristocracy. Museum staff are dressed in period costume, which certainly adds to realism. It would take an expert to tell whether the clothing worn was truly authentic, even if modern spectacles, watches and shoes, being anachronistic, do somewhat detract from the overall effect.

The Royal Armouries Museum has put re-enactment on a serious footing by employing professional actors to perform scenes involving war. An actor plays the part of a soldier at the battle of Rorke's Drift against the Zulus in 1879, telling of his thoughts as he dramatically fires upon the enemy, and as his comrades are killed. Children are understandably somewhat overwhelmed by the performance, but in all probability will not forget the experience. At the end the actor calls for questions. That most frequently put concerns authenticity: how does the actor actually know what happened, how does he know what passed through the mind of someone living more than a century ago when values were very different, and are the rifle and uniform exactly correct? In truth, all the actor can say is that as far as the Royal Armouries' research can reveal, everything is authentic. The same general issues are raised in the reenactment of a First World War officer who relishes battle, and of another who is despondent about the stupidity of war. Such re-enactment unquestionably leaves a lasting impression on the tourist and is to be welcomed. After such impressive performances it is somewhat disappointing to find that the firing of blank cartridges in Second World War artillery pieces is undertaken by men wearing modern denims. But the accompanying noise, smoke and flash enthral the audience.

Similarly, mock battles may be entertaining, but their authenticity is questionable, even if they are staged at the precise 
uwierzyć, że to, co się dzieje, dzieje się naprawdę, ponieważ nikt nie zostaje zabity, a walka wręcz w dużej mierze zależy od kaprysu dzisiejszych uczestników. Jeden z komentatorów postrzega inscenizację jako „legalny historyczny huliganizm" (HEWISON 1970), podczas gdy BONIFACE i FOWLER (1997) twierdzą niebezpodstawnie, że zwiedzający zaczęli oczekiwać superrealizmu lub „poprawionej” rzeczywistości. Puryści mogą nie być tym zachwyceni, ale rekonstrukcja stała się częścią turystyki zorientowanej na poznanie dziedzictwa narodowego i mimo że nie jest w sposób oczywisty autentyczna, powinna być zaakceptowana.

\subsection{CHLUBNE I TRUDNE DZIEDZICTWO}

Istnieje naturalna tendencja, by postrzegać dziedzictwo w odniesieniu do wydarzeń i artefaktów, które wywolują dumę i pozytywne uczucia. Spotykamy się z wielkim poparciem dla instytucji monarchii i całej gali z nią związanej, dla tradycji wojskowych i zwycięskich bitew, takich jak ta pod Trafalgarem w 1805 r. i pod Waterloo w 1815 r., dla systemu nadawania godności, jak pasowanie na rycerza lub para, tym, którzy na to zasłużyli. Pola bitewne I wojny światowej we Francji i Belgii stały się popularnym elementem mapy turystyki zorientowanej na poznanie dziedzictwa narodowego. Nawet przegrane bitwy moga być przekształcone $\mathrm{w}$ heroiczne zdarzenia: ewakuacja spod Dunkierki w 1940 r. była spowodowana pogromem armii brytyjskiej przez Wermacht, ale jest powszechnie przedstawiana nie jako porażka, ale jako wybitnie bohaterskie wydarzenie ukazujące brytyjską determinację przetrwania.

Sławne osoby, począwszy od rodziny królewskiej, poprzez dramatopisarzy, takich jak Szekspir, wielkich przywódców, jak Nelson i Churchil, do luminarzy, jak the Beatles, sq uwielbiane przez wieki, a ich domy to naturalny komponent turystyki zorientowanej na poznanie dziedzictwa narodowego.

Jednakże zaczyna się akceptować fakt, iż dziedzictwo obejmuje również wydarzenia, które nie sa powodem do dumy narodowej, a mimo to niektóre muzea zaczęły to pokazywać. Wiodąca rola Wielkiej Brytanii w przymusowej migracji 14-20 mln czarnej ludności z Afryki do Indii Zachodnich i Nowego Świata jako niewolników (RANSFORD 1971), prezentowana jest obecnie przez the National Maritime Museum i the Liver- location of the historic event. An example is the battle of Culloden, Scotland, the last battle fought in Britain, in 1746, when the Scottish Highlanders were crushed by the English army. The site of the battle is simply a field where the event is re-enacted, and there is even a visitor centre containing visual information. But belief has to be suspended since nobody is actually killed, and the hand to hand fighting very much depends on the whim of the present-day participants. One commentator sees these events as "licensed historical hooliganism' (HEwISON 1987), while BONIFACE and FOWLER (1997) claim not unreasonably that visitors have come to expect hyper-reality, or an 'improvement' on reality. Purists may carp, but re-enactment has become part of heritage tourism, and unless it is blatantly inauthentic, it should be accepted.

\subsection{GLORIOUS AND DIFFICULT HERITAGE}

There is a natural tendency for heritage to be seen with reference to events and artefacts which generate pride and positive feelings. There is much support for the institution of monarchy and all its pageantry, for military traditions and successful battles such as Trafalgar in 1805 and Waterloo in 1815, and for the honours system which bestows knighthoods and peerages upon the deserving. The First World War battlefields in France and Belgium have become a popular element on the heritage tourism map. Even defeats can be manipulated into heroic happenings: the evacuation from Dunkirk in 1940 was caused by the rout of the British Army by the Wehrmacht, but is generally presented not as a defeat, but as an outstandingly courageous event demonstrating British determination to survive. Famous personages ranging from royalty, playwrights such as Shakespeare, great leaders such as Nelson and Churchill, to luminaries such as the Beatles, are revered by many and their residences are a legitimate component of heritage tourism.

However, there is a gradual appreciation that heritage also includes events which do not redound to a nation's favour and some museums have laudably begun to hint at this. The leading role played by Britain in 
pool Maritime Museum. Ale wynalezienie obozu koncentracyjnego przez generała Kitchenera podczas wojny burskiej (Boer) w latach 19001902 (a nie przez nazistów w 1935 r.) (WILSON 2002), nie zostało jeszcze przyjęte przez turystykę zorientowaną na poznanie dziedzictwa narodowego. Religijna walka w Irlandii Północnej, gdzie 3600 osób zginęło od 1969 r., jest zbyt bliska w czasie historycznym, by objawiła się jako dziedzictwo. Trudna spuścizna może nigdy nie zając ważnego miejsca w turystyce dziedzictwa ze względu na swój negatywny wydźwięk, ale przynajmniej przestała być pomijana.

\subsection{WYTWARZANIE DOCHODU}

Potrzeba wytwarzania dochodu w pewien sposób przyczyniła się do rozwoju turystyki dziedzictwa poprzez rozbudowę infrastruktury dla zwiedzających. Kawiarnia i księgarnia stały się obecnie standardem $w$ miejscach dziedzictwa, a większe muzea $\mathrm{z}$ powodzeniem zajęły się sprzedażą detaliczna. The British Museum np. sprzedaje szeroki wachlarz produktów odnoszących się do muzealnych artefaktów. Wiadomo, że towary W sklepie przyciagają niektórych turystów nawet bardziej niż samo muzeum (HUNTER 2002). The British Museum oferuje teraz wykwintny obiad pośród marmurów z Elgin, płaskorzeźby zabranej z Partenonu w Atenach w latach 1801-1803. Niektóre zamki szkockie zapewniają średniowieczną ucztę, podczas której potrawy, zastawa, oświetlenie, muzyka i obsługa wiernie oddają warunki tamtych czasów. Szczególnie Amerykanie lubują się w tego rodzaju turystyce. Zakładając, że rodzice są gotowi zapłacić znaczną sumę, by wyprawić dzieciom niezapomniane wesele, wiele prawdopodobnie większość - miejsc dziedzictwa wynajmuje swój teren na przyjęcia weselne, zapewniając namioty, jedzenie i muzykę. Znany z takich przyjęć jest Warrior, którego dochód W nieco więcej niż połowie pochodzi z tego źró$\mathrm{d} \mathfrak{}$ a. Popyt na przywilej świętowania w tak niezwykłym otoczeniu jest tak wielki, iż statek trzeba rezerwować z 18-miesięcznym wyprzedzeniem. Niektóre hotele oferują obecnie coś, co nazywają golfowymi lub wędkarskimi wakacjami z dziedzictwem. Można by stwierdzić, że tego rodzaju pomysły przesuwają granice pojęcia ,dziedzictwo" zbyt daleko.

Jedną z cech charakterystycznych wielu miejsc dziedzictwa, zwłaszcza tych, które znajdują się w rękach prywatnych, jest duże znaczenie ochot- the forced migration of between 14 to 20 million black people from Africa to the West Indies and the New World as slaves (RANSFORD 1971) is now featured in displays at the National Maritime Museum and the Liverpool Maritime Museum. But the invention of the concentration camp by General Kitchener during the Boer War 1900-2, rather than by the Nazis in 1935 (WILSON 2002), has not yet been recognised by heritage tourism. The religious strife in Northern Ireland, where 3,600 people have died since 1969 , is too close in historical time for it to appear as heritage. Difficult heritage may never occupy an important part in heritage tourism because of its negative overtones, but at least it is not now being overlooked.

\subsection{THE GENERATION OF INCOME}

The need to generate income has in some ways contributed to an increase in heritage tourism through the creation of facilities for visitors. It is now standard for heritage sites to provide a cafe and bookshop, while the larger museums have effectively moved into retailing. The British Museum, for instance, sells a wide range of items relating to the Museum's artefacts, and it is known that some tourists are attracted by the shop's goods even more than by the Museum itself (HUNTER 2002). The British Museum now offers a sumptuous dinner with a backdrop of the Elgin marbles, a low relief frieze removed from the Parthenon in Athens in 1801-3. Some Scottish castles provide a medieval banquet at which the food, cutlery, lighting, music and serving wenches mirror contemporary conditions. Americans in particular find this kind of heritage tourism especially attractive. Appreciating that parents appear to be prepared to pay substantial sums of money to celebrate their children's marriages, many - probably a majority - of heritage sites hire their premises for the wedding reception, providing marquees, food and music. So popular for these receptions is Warrior that slightly more than half its visitor income is derived in this way. It is necessary to reserve the ship 18 months in advance, such is the demand for the privilege of celebrating in such an unusual heritage environment. 
ników, bez których niektóre miejsca musiałyby zostać zamknięte. W roku 2000 spośród 70000 pracowników muzeów 30000 (45\%) było ochotnikami. Są to przeważnie emerytowane osoby pochodzące $z$ klasy średniej, które czują że mogą jeszcze coś z siebie dać, albo młodzi ludzie, którzy $w$ ten sposób zgłębiają swoje zainteresowania. Można ich znaleźć na wszystkich zabytkowych liniach kolejowych, pracuja jako przewodnicy, urzędnicy, obsługa w kawiarni, personel pociagu czy techniczny (OSBORNE 2002). Ciekawe jest, że turystyka zorientowana na poznanie dziedzictwa daje satysfakcję zarówno turystom, jak i osobom pracującym bez wynagrodzenia, by upewnić się, iż dziedzictwo jest dostępne do konsumpcji publicznej. Nie ma wielu sektorów gospodarczych tak zależnych od ochotniczej pracy. Pojedyncze osoby wspieraja ten typ turystyki, lecz jednocześnie otrzymuje ona bardzo konkretne wsparcie finansowe od the Heritage Lottery Fund, fundacji, która między rokiem 1994 a 2004 ustanowiła 15000 nagród dla projektów dziedzictwa na łączną sumę 3 mld funtów. Muzea i inne instytucje poświęcają teraz dużo czasu na przygotowanie wniosków do the Heritage Lottery Fund.

Turystyka nastawiona na poznawanie dziedzictwa odbiega daleko od działalności wolnorynkowej, przynajmniej w Wielkiej Brytanii.

\section{WNIOSKI}

Turystyka zorientowana na dziedzictwo kulturowego spotkała się ze złą opinią ze strony naukowców, którzy wydają się opisywać tylko te aspekty, które ponoszą winę za uproszczenia. Szczególnie krytyczny jest LOWENTHAL (1998): „Historia po prostu jest. Dziedzictwo jest tym, czym chcielibyśmy by było. (...) Dziedzictwo przesadza i pomija, szczerze wymyśla i uczciwie zapomina, żywi się ignorancją i błędem." Jednakże na potwierdzenie tego, co zaprezentowano powyżej, duża część podaży dziedzictwa kulturowego przedstawiana jest stosunkowo odpowiedzialnie, w żadnym przypad$\mathrm{ku}$ nie zmierza jedynie do bawienia turysty. Wbrew opinii Lowenthala, powinno się podkreślić, iż sama historia opiera się na interpretacji, która zmienia się wraz z upływającym czasem, czyniąc prawdę historyczną coraz bardziej złudną (RILEY 1999).
Some hotels now even offer what they describe as heritage golf and heritage fishing holidays; it is submitted that this is stretching the definition of heritage too far.

One characteristic of many heritage sites, above all those in private hands, is the importance of volunteers, without which some would have to close. In 2000, out of 70,000 museum workers, 30,000 (45\%) were volunteers. Volunteers are largely retired middle class people who feel they have something to offer, or younger people indulging their hobby. They are to be found working on all preserved railway lines working as guides, clerks, café personnel, train staff and engineers (OSBORNE 2002). It is therefore curious that heritage tourism gives satisfaction both to tourists and to staff who work for nothing to ensure that heritage is available for public consumption. There cannot be many economic sectors so reliant on free labour. Individuals thus subsidise heritage tourism, but at the same time the sector receives very substantial financial support from the Heritage Lottery Fund, which between 1994 and 2004 made 15,000 awards to heritage projects worth $£ 3$ billion. Museums and other bodies now spend considerable amount of time preparing their applications to the Heritage Lottery Fund. Supply-side heritage tourism, in Britain at least, is far from being a free market activity.

\section{CONCLUSION}

Heritage has received a bad press from some scholars who appear to be describing only those aspects which are certainly guilty of dumbing down. LOWENTHAL (1998) is particularly critical: 'History is, heritage is what we would like it to be'; 'Heritage exaggerates and omits, candidly invents and frankly forgets, and thrives on ignorance and error'. However, on the evidence offered here, much supply-side heritage is presented reasonably responsibly, by no means being driven only to entertain the heritage tourist. In rebutting Lowenthal's remarks, it should be pointed out that history is itself based on interpretation, a notion which itself changes through time, making historical truth increasingly elusive (RILEY 1999). 


\section{BIBLIOGRAFIA - BIBLIOGRAPHY}

Ashworth, G., HOWARD, P., 1999, European Heritage Planning, Intellect.

BONIFACE, P., FOWLER, P. J., 1993, Heritage and Tourism in the Global Village, Routledge.

Hewison, R., 1987. The Heritage Business in Britain in a Climate of Decline, Methuen.

HunTER, Ch., 2002, Why do we Buy Heritage Merchandise? A Decision-Making Framework, unpublished MSc Dissertation, University of Portsmouth.

LOWENTHAL, D., 1998, The Heritage Crusade and the Spoils of History. Cambridge University Press.

\section{Podziękowanie}

Chciałbym zlożyć wyrazy wdzięczności Profesorowi Marinowi Bachvarovowi, z którym przeprowadziliśmy wiele owocnych dyskusji na temat turystyki nastawionej na poznawanie dziedzictwa przed Jego przedwczesną śmiercią. Niewątpliwie odniósłby się do problemu, korzystając $z$ niektórych uwag poczynionych w powyższym artykule.
OsBORNE, R., 2002, The Effect of Museum Types on the Profile and Motivation of Museum Volunteers, unpublished MSc Dissertation, University of Portsmouth.

RANSFORD, O., 1971, The Slave Trade, Readers Union.

RILEY, R., 1999, A Model-Based Approach to Unravelling Naval Defence Heritage. Supply- and Demand-Side Issues in Portsmouth's Coastal Zone, Ocean and Coastal Management, 42(10), 891-908.

RILEY, R., 2005, Maritime City. Portsmouth 1945-2005. Sutton.

WILSON, A. N., 2002, The Victorians, Hutchinson.

\section{Acknowledgement}

I wish to record my gratitude to Professor Marin Bachvarov, with whom I had many fruitful discussions on the subject of heritage tourism prior to his recent untimely death. Undoubtedly he would have taken issue with some of the remarks made in this paper. 